\title{
PENGELOLAAN SUMBER DAYA AIR PASCA DIBATALKANNYA UNDANG-UNDANG NOMOR 7 TAHUN 2004 TENTANG SUMBER DAYA AIR
}

\section{WATER RESOURCE MANAGEMENT AFTER THE CANCELLATION OF LAW NUMBER 7 OF 2004 CONCERNING WATER RESOURCES}

Agus Surachman

\author{
Program Doktor Fakultas Hukum, \\ Universitas Negeri Sebelas Maret . \\ Korespondensi : Agus Surachman, Tel. 081297479159 \\ e-mail : surachman.ozzz@yahoo.com
}

Jurnal Abstract : Law Number 7 of 2004 on Water Resources was officially revoked by the Living Law, Constitutional Court because it contradicted Article 33 of the 1945 Constitution. The Vol. 11, No. revocation is also applied to all implementing regulations thereunder resulting in a

2, 2019

hlm. 96-105 legal vacuum. To fill the legal void and to wait for the new Water Resources Law, the Constitutional Court decided to re-enact Law no. 11 Year 1974 on Watering. With the revocation of the Water Resources Act, it restores the community's rights to clean water privatization by the private sectors. But, the impact for the government is that the control over the water is controlled by the state again. For drinking water business, the revocation of the Water Resources Law causes legal uncertainty resulting from the withdrawal of all implementing regulations so that there is no law available. The research method used is normative method, by collecting data of primary, secondary and tertiary law. What should be done by the government is to immediately draft a new Water Resources Act in accordance with the mandate of Article 33 of the 1945 Constitution, and the participation of private parties should be regulated but still limited and it is the State that manages the water resources.

Keywords: Water Resources, Cancellation of the Law.

Abstrak : Undang-Undang No. 7 Tahun 2004 tentang Sumber Daya Air resmi dicabut oleh Mahkamah Kontitusi karena bertentangan dengan Undang-Undang Dasar 1945 Pasal 33. Pencabutan Undang-Undang No 7 Tahun 2004 tersebut juga berlaku untuk semua peraturan pelaksana dibawahnya sehingga mengakibatkan terjadinya kekosongan hukum. Untuk mengisi kekosongan hukum tersebut dan menunggu Undang-Undang Sumber Daya Air yang baru, maka MK memutuskan diberlakukan kembali Undang-Undang No. 11 Tahun 1974 tentang Pengairan. Dengan dibatalkannya Undang-Undang Sumber Daya Air, maka mengembalikan hak-hak masyarakat atas air bersih yang selama ini diprivatisasi oleh swasta. Namun dampak bagi pemerintah sendiri adalah penguasaan atas air kembali dikuasai oleh negara. Untuk usaha air minum sendiri atas pencabutan UU SDA menyebabkan ketidakpastian hukum yang diakibatkan dicabutnya semua peraturan pelaksana sehingga belum tersedianya payung hukum. Metode penelitian yang digunakan adalah metode normatif, dengan mengumpulkan data-data hukum primer, sekunder maupun tersier. Yang harus dilakukan oleh pemerintah adalah segera membuat draf Undang-Undang Sumber Daya Air yang baru yang sesuai dengan amanat Pasal 33 Undang-Undang Dasar 1945 dan keikutsertaan pihak swasta harus diatur namun tetap dibatasi dan negara yang mengelola atas sumber daya air tersebut.

Kata Kunci : Sumber Daya Air, Pembatalan Undang-Undang. 


\section{PENDAHULUAN}

Air merupakan salah satu aspek penting dalam dunia pertanian mengingat posisinya sebagai salah satu kebutuhan penting bagi tanaman terutama tanaman pada lahan basah. Kebutuhan air pertanian banyak dipenuhi melalui irigasi. Sistem irigasi yang ada di Indonesia bersumber dari adanya aliran sungai maupun sumbersumber mata air. Kualitas aliran sungai dan sumber mata air yang baik menjadi hal yang penting. Kuantitas air dari sumber irigasi pun turut menjadi penentu kelancaran proses bercocok tanam para petani. ${ }^{1}$ Bahwa sumber daya air merupakan karunia Tuhan Yang Maha Esa yang memberikan manfaat untuk mewujudkan kesejahteraan bagi seluruh rakyat Indonesia dalam segala bidang. ${ }^{2}$

Kekurangan air bersih, tentu akan berpengaruh pada kualitas hidup, terutama dalam hal sanitasi dan kesehatan. Pada tingkat yang ekstrim, tidak adanya akses terhadap air bersih akan menyebabkan kematian. Satu dari delapan kematian di dunia, disebabkan karena tiadanya akses terhadap air bersih, dan jumlah itu menurut National Geographic mencapai 3,3 juta jiwa per-tahun. ${ }^{3}$

Berdasarkan data PBB pada tahun 2003, terdapat 1,3 miliar orang di dunia tidak memiliki akses yang cukup pada air bersih. Selain itu, persoalan defisit air juga melanda 31 negara di berbagai belahan dunia. Jumlah kebutuhan air meningkat pesat selama 20 tahun terakhir terkait dengan peningkatan jumlah penduduk. Selain masalah ketersediaan air, juga mengahadapi permasalahan pencemaran yang diakibatkan oleh aktivitas industri dan domestik. ${ }^{4}$

\footnotetext{
1 Green Trust Petani 3 September 2010, "Akses Air Untuk Pertanian Berkelanjutan". Green Trust Petani. Halaman : 4-5.

2 Indonesia, Menimbang huruf a Undang-Undang No. 7 Tahun 2007 tentang Sumber Daya Air.

3 "Ironi Air di Indonesia Menyikapi Potensi Perang Air Belajar Tentang Air dari Swedia" dari Sustaining Partnership Edisi Desember 2011

4 Pada 2050 Dua Pertiga Penduduk Dunia Kekurangan

Air"
}

Penguasaan atas sumber daya air harus dikuasai oleh negara, hal tersebut sejalan dengan Pasal 33 ayat (3) Undang-Undang Dasar Negara Republik Indonesia Tahun 1945, yang menyatakan bahwa sumber daya air dikuasai oleh negara dan dipergunakan untuk sebesar-besar kemakmuran rakyat secara adil. Atas penguasaan sumber daya air oleh negara, negara menjamin hak setiap orang untuk mendapatkan air bagi pemenuhan kebutuhan pokok sehari-hari dan melakukan pengaturan hak atas air. Penguasaan negara atas sumber daya air tersebut diselenggarakan oleh Pemerintah pusat atau pemerintah daerah dengan tetap mengakui dan menghormati kesatuankesatuan masyarakat hukum adat beserta hak-hak tradisionalnya. ${ }^{5}$ Untuk menjamin hal tersebut maka dikeluarkan UndangUndang No. 7 Tahun 2004 tentang Sumber Daya Air. Namun banyak pihak yang menolak Undang-Undang tersebut dikarenakan adanya privatisasi air oleh swasta sudah tersirat dalam UndangUndang tersebut, khususnya melalui pengaturan pengusahaan SDA pada Pasal 7, Pasal 8, Pasal 9, Pasal 26, Pasal 38, Pasal 40, Pasal 45, Pasal 46, Pasal 47, dan Pasal 49. Pasal-pasal itu dapat menjadi pintu masuknya perorangan dan badan hukum swasta. Dengan keluarnya Keputusan Mahkamah Konstitusi (MK) Nomor 85/PUU-XI/2013 memutuskan bahwa Undang-Undang No. 7 Tahun 2004 Tentang Pengolahan Sumber Daya Air (SDA) dan semua peraturan di bawahnya dibatalkan. ${ }^{6}$

\section{METODE PENELITIAN}

Metode penelitian yang digunakan adalah metode normatif, dengan

dalam http://nationalgeographic.co.id/berita/2012 109/pada-2050-dua-pertiga-penduduk-duniakekurangan-air, diakses pada 8 Desember 2017. 5Penjelasan Undang-Undang No. 7 Tahun 2007 tentang Sumber Daya Air.

${ }^{6}$ http://www.hukumonline.com/berita/baca/lt54e4 bd8e5dc0a/mk-batalkan-uu-sumber-daya-air, diakses pada 8 Desember 2017. 
mengumpulkan data-data hukum primer, sekunder maupun tersier.

\section{PEMBAHASAN}

\section{A. LAHIRNYA UNDANG-UNDANG NO 7 TAHUN 2004}

Undang-Undang Nomor 7 Tahun 2004 tentang Sumber Daya Air lahir atas tekanan Bank Dunia melalui WATSAL (Water Resources Sector Adjustment Loan); Memperkenalkan paradigma air memiliki "economic and social function" sebagai upaya mengakomodasi gagasan economic value dari air sebagai economic good dan hak-hak asasi manusia atas air sebagai public good (Pasal 4 UUSDA). ${ }^{7}$

Berkaitan dengan privatisasi sangat erat kaitannya dengan lembaga keuangan internasional diantaranya WTO (World Trade Organization), IMF (Internasional Monetery Fund), Bank Dunia (World Bank). Ketiga lembaga ini merupakan pelopor dalam munculnya berbagai kebijakan privatisasi dan liberalisasi sebagai prasyarat dalam memberikan pinjaman ke setiap negara utamanya di negara berkembang atau dunia ke tiga. ${ }^{8}$

Privatisasi air adalah berpindahnya pengelolaan air baik sebagian maupun seluruhnya dari sektor publik kepada sektor swasta. Kurang lebih dua dekade terakhir ini, privatisasi air menjadi salah satu isu pembangunan yang paling kontroversial. Dampak turunannya, kini kian banyak negara di dunia yang berlomba membuat kebijakan privatisasi air. ${ }^{9}$

Untuk di Indonesia sendiri, privatisasi air sudah berlangsung sejak Bank Dunia memberikan pinjaman utang dengan kesepakatan WATSAL(Water Resource

\footnotetext{
7 AL. Sentot Sudarwanto, Dampak Dibatalkannya Undang-Undang Nomor 7 Tahun 2004 Tentang Sumber Daya Air Terhadap Manajemen Air untuk Kesejahteraan Masyarakat, Yustisia. Vol. 4 No. 2 Mei - Agustus 2015.

8 http://verlye.blogspot.co.id/2013/02/dampakprivatisasi-air-terhadap.html, 8 Desember 2017 ${ }^{9}$ Ibid.
}

Sector Adjusment Loan atau Pinjaman Penyesuaian Sektor Sumber Daya Air). Bank Dunia pada awal pembentukannya disebut dengan IBRD (Internasional Bank for Recontruction and Development) yang dibentuk pada 27 Desember 1945, yang lahir dari konferensi internasional di kota Breeton Woods, New Hampshire, Amerika Serikat yang dihadiri 44 negara. Konferensi internasional tersebut bertujuan untuk membangun kembali ekonomi dunia setelah perang dan bagaimana konferensi tersebut dapat menyepakati hal-hal yang dapat mengurangi kebijakan perdagangan, pembayaran dan nilai tukar yang memiliki dampak yang menghambat perdagangan. Sehingga dikenal dengan Sistem Breeton Woods. Namun seiring dengan berakhirnya perang, kini lembaga yang bermarkas di Washington ini juga berfungsi dalam memberikan bantuan kepada negara berkembang untuk mengentaskan kemiskinan. Namun dalam realitasnya bahwa Bank Dunia mengusung berbagai agenda yang menjadi misinya salah satunya yaitu, Deregulasi, liberalisasi dan privatisasi.

Pada pertengahan 1999, disetujui pinjaman WATSAL bagi Indonesia senilai USD 300 Juta. Namun, dalam memberikan pinjaman tersebut, Bank Dunia mensyaratkan pemerintah Indonesia untuk melakukan reformasi dibidang pengelolahan air. Pemberian pinjaman oleh Bank Dunia ini bertujuan ini dengan dalih penguatan institusi dan perangkat hukum untuk pengolalahan sumber daya daerah aliran sungai (DAS), pengelolahan polusi air, dan pengelolahan sumber daya air dan sistem irigasi. WATSAL merekomendasikan kebijakan Indonesia untuk berfokus pada 3 tema utama yaitu 1) Analisa kerangka kerja keseluruhan untuk mengidentifikasi prioritas (holistic planning); 2) Sistem kelembagaan dan regulatory yang didukung oleh legistalif dan pendukung perubahan (menekankan pada desentralisasi dan partisipasi) dan 3). financial and opportunity cost problems 
generated from waterand its utilisation in a competitive base (sebagai barang ekonomi). ${ }^{10}$

Skema full cost recovery yang dicanangkan Bank Dunia itu terbukti masuk dalam agenda reformasi kebijakan air di Indonesia sebagaimana tertuang dalam Kebijakan Nasional SDA 2001. Pasal 4 huruf (g) menyatakan Arah kebijakan pengelolaan sumber daya air secara umum adalah

Kebijakan full cost recovery ini bahkan dinyatakan pula secara lebih tegas dan rinci dalam Pasal 60, Peraturan Pemerintah No. 16 Tahun 2005 tentang Pengembangan Sistem Penyediaan Air Minum. Pasal tersebut berbunyi:

1. Tarif air minum merupakan biaya jasa pelayanan air minum dan jasa pelayanan air limbah yang wajib dibayar oleh pelanggan untuk setiap pemakaian air minum yang diberikan oleh Penyelenggara;

2. Perhitungan dan penetapan tarif air minum sebagaimana dimaksud dalam ayat (1) harus didasarkan pada prinsip-prinsip:

- keterjangkauan dan keadilan;

- mutu pelayanan;

- pemulihan biaya;

- efisiensi pemakaian air;

- transparansi dan akuntabilitas; dan

- perlindungan air baku.

3. Komponen biaya yang diperhitungkan dalam perhitungan tarif meliputi:

- biaya operasi dan pemeliharaan;

- biaya depresiasi/amortisasi;

- biaya bunga pinjaman;

- biaya-biaya lain; dan

- keuntungan yang wajar.

Ketentuan dalam PP No. 16/2005 di atas, khususnya ayat (3), secara sangat nyata berseberangan dengan tafsir MK atas UUSDA. Persoalan sesungguhnya bukan pada PP, tapi pada original intent dari PP

10 Basah Hernowo, Kebijakan Nasional Pengelolaan Sumber Daya Air, Direktorat Kehutanan dan Konservasi Sumber Daya Air, Kementrian PPN/BAPPENAS
16/2005 hanya melaksanakan original intent dari UUSDA 2004. ${ }^{11}$

Privatisasi air yang membatasi hak setiap orang untuk mengakses air pada dasarnya sangat bertentangan dengan keputusan Perserikatan Bangsa-Bangsa pada November 2002 yang mengesahkan air sebagai hak asasi manusia dalam International Convenant on Economic, Social, and Cultural Rights. ${ }^{12}$

Dengan demikian maka menghilangkan akses seseorang atas air tidak lain merupakan pelanggaran hak asasi manusia yang berkaitan dengan hak untuk hidup dan kemerdekaan serta keamanan pribadi yang sangat fundamental. ${ }^{13}$

Pelaksanaan atas hak menguasai Negara tetap menghormati hak yang dimiliki oleh masyarakat adat setempat, sepanjang tidak bertentangan dengan kepentingan nasional.

Meski mengakui ketrlibatan swasta dijamin dalam UU SDA dan Putusan MK No. 058-059-060-063/PUU-II/2004 dan No. 008/PUU-III/2005 yang mengakui peran swasta dan telah mewajibkan pemerintah memnuhi hat atas air sebagai kebutuhan pokok, di luar hak guna air. Namun, penafsiran MK itu telah diselewaengkan secara normatif yang berdampak teknis pelaksanaannya.

Hal ini dapat dilihat Pasal 1 angka 9 Nomor 16 Tahun 2005 tentang Pengembangan sistem Penyediaan Air Minum (SPAM) yang menyebut penyelenggara pengembangan SPAM adalah BUMN/BUMD, koperasi, badan usaha swasta atau kelompok masyarakat. Padahal, Pasal 40 ayat (2) UU SDA sudah menyatakan pengembangan SPAM tanggung jawab pemerintah pusat/pemerintah daerah.

\footnotetext{
${ }^{11}$ AL. Sentot Sudarwanto, Op.cit.

12 Anonim, Komersialisasi Air Abaikan Rakyat Miskin RUU Sumber Daya Air Harus Ditinjau Ulang, dalam http://www.unisosdem.org/article detail.php? aid $=2632$ \& coid $=3 \&$ caid $=3 \&$ gid $=5$, diakses pada 8 Desember 2017

13 Pasal 3 Deklarassi Universal Hak Asasi Manusia menyatkan " Everyone has the right to Life, Liberty and Security of Person."
} 
Ini artinya, PP Nomor 16 tahun 2005 merupakan swastanisasi terselubung dan pengingkaran tafsir konstitusional MK. Kondisi ini telah melahirkan mindset pengelolaan air yang selalu profit oriented dengan keuntungan maksimum bagi pemegangn saham. Hal ini jelas pasal-pasal privatisasi itu bertentangan dengan Pasal 33 UUD 1945, sehingga harus dinyatkan batal.

Dikutif dari International Journal of Economic Research, pendapat Agus Surachman mengatakan :

"...necessary to create a law that guarantees the sovereignty of water resources for graetest prosperity of the Indonesian people and a clear understanding of Article 33, especially Paragraph 4. This means that the private sector may not exercise control over water resources but is limited to exploit them in certain amount or allocations in accordance with what strictly granted by state. Wate should not be view economic comodity but it has a social function because it is grace of God for all mankind and not for the benefit of any individual or group of bussinesmen." 14

Jimly Asshiddiqie menegaskan bahwa salah satu prinsip pokok negara hukum (rechtstaat) adalah adanya perlindungan konstitusi terhadap hak asasi manusia dengan jaminan hukum bagi tuntutan penegakannya melalui proses yang adil. ${ }^{15}$ Sependapat dengan hal tersebut, Bagir Manan menyatakan bahwa :

"negara berdasarkan konstitusi, mengandung sekurang-kurangnya dua makna. Pertama: pengaturan mengenai batas peran negara atau pemerintahan dalam mencampuri kehidupan dan pergaulan masyarakat. Kedua; jaminan hukum dan hak-hak, baik sipil maupun

\footnotetext{
14 Agus Surachman dkk, Effect of Globalization on Establihment of Water Resource Law: A Practice in Indonesia, International Journalof Economic Research ISBN: 0972-9380, Volume 14. No 12 Tahun 2017, hlm. 98.

15 Jimly Assiddiqie, Konstisusi dan Konstitualisme Indonesia, (Jakarta: MKRI \& Pusat Studi HTN FHUI, 2004), hlm. 123-128.
}

pribadi (individual right) maupun hak-hak sebuah kelompok ata sosial..."16

Selain Pasal 33 UUD 1945 terdapat frasa "dikuasai oleh negara" terdapat Undang-Undang lain yang yang memberikan pengertian mengeni penguasaan oleh Negara yaitu UndangUndang Nomor 5 Tahun 1960 tentang Peraturan Dasar Pokok-pokok Agraria (UUPA). Dalam Pasal 2 UUPA diatur bahwa hak menguasai dari Negara memberi wewenang untuk :

1. Mengatur dan menyelenggarakan peruntukan, penggunaan, persediaan, dan pemeliharaan bumi, air dan ruang angkasa;

2. Menentukan dan mengatur hubunganhubungan hukum antara orang-oreng dengan bumi, air, dan ruang angkasa;

3. Menentukan dan mengatur hubunganhubungan hukum antara orang-orang dan perbuatan-perbuatan hukum yang mengenai bumi, air, dan ruang angkasa.

Dalam Pasal 2 ayat (3) UUPA, wewenang yang bersumber pada hak menguasai dari Negara tersebut dipergunakan untuk mencapai sebesarbesar kemakmuran rakyat dalam arti kebangsaan kesejahteraan dan kemerdekaan dalam masyarakat dan negara hukum Indonesia yang merdeka, berdaulat, adil dan makmur. Selain dalam UUD 1945 dan UUPA, dalam UndangUndang Nomor 11 Tahun 1974 tentang Pengairan diatur pula bahwa:

1. Air beserta sumber-sumbernya termasuk kekayaan alam yang terkandung didalamnya dikuasai oleh Negara;

2. Hak menguasai oleh Negara memberi wewenang kepada pemerintah untuk :

a. Mengelola serta mengembangkan kemanfaatan air dan/atau sumbersumber air;

b. Menyusun, mengesahkan dan atau memberi izin berdasarkan perencanaan dan perencanaan teknis

16 Bagir Manan, Toeri dan Politik Konstitusi, (Yogyakarta: FHUII, 2003), hlm. 244-245. 
tata pengaturan air dan tata pengairan;

c. Mengatur, mengesahkan dan atau memberi izin peruntukan, penggunaan, penyediaan air dan/atau sumber-sumber air;

d. Mengatur, mengesahkan dan atau member izin pengusahaan air dan/atau sumber-sumber air;

e. Menentukan dan mengatur perbuatan-perbuatan hukum dan hubungan-hubungan hukum antara orang dan atau badan hukum dalam persoalan air dan sumber-sumber air.

\section{B. DAMPAK PEMBATALAN UNDANG- UNDANG SUMBER DAYA AIR}

Pembatalan pemberlakuan UndangUndang No 7 Tahun 2007 tentang Sumber Daya Air melalui putusan MK merupakan yang monumental dikarenakan putusan ini merupakan kali kedua MK memutuskan untuk membatalkan keseluruhan melalui pengujian materi norma. ${ }^{17}$

Mahkamah Konstitusi

(MK) membatalkan keberlakuan secara keseluruhan Undang-Undang Nomor 7 Tahun 2004 tentang Sumber Daya Air (SDA) karena tidak memenuhi enam prinsip dasar pembatasan pengelolaan sumber daya air. Demikian putusan dengan Nomor 85/PUU-XII/2013 menyatakan Undang-Undang Nomor 7 Tahun 2004 tentang Sumber Daya Air bertentangan dengan UUD 1945. Dalam pendapat Mahkamah putusan terkait UU SDA juga telah dipertimbangkan dalam putusan Putusan Nomor 058-059-060-063/PUUII/2004 dan Nomor 008/PUU-III/2005.18 Dalam pertimbangannya, MK menyatakan bahwa sumber daya air sebagai bagian dari hak asasi, sumber daya yang terdapat pada

17 Ibnu Sina Chandranegara, Ultra Pelitan dan Keadilan menuju Konstitusi, Jakarta: Jurnal Konstitusi. Volume 9 No. 1 (2012) hlm. 36.

${ }^{18}$ http://www.mahkamahkonstitusi.go.id/index.php ?page=web.Berita\&id=10634\#.Win2-NKWbcc, $\quad M K$ batalkan UU Sumber Daya Air, diakses pada 9 Desember 2017. air juga diperlukan manusia untuk memenuhi kebutuhan lainnya, seperti untuk pengairan pertanian, pembangkit tenaga listrik, dan untuk keperluan industri, yang mempunyai andil penting bagi kemajuan kehidupan manusia dan menjadi faktor penting pula bagi manusia untuk dapat hidup layak. ${ }^{19}$

"Persyaratan konstitusionalitas UU SDA tersebut adalah bahwa UU SDA dalam pelaksanaannya harus menjamin terwujudnya amanat konstitusi tentang hak penguasaan negara atas air. Hak penguasaan negara atas air itu dapat dikatakan ada bilamana negara, yang oleh UUD 1945 diberi mandat untuk membuat kebijakan (beleid), masih memegang kendali dalam melaksanakan tindakan pengurusan (bestuursdaad), tindakan pengaturan (regelendaad), tindakan pengelolaan (beheersdaad), dan tindakan pengawasan (toezichthoudensdaad)"20

Kemudian konsep hak dalam Hak Guna Air harus dibedakan dengan konsep hak dalam pengertian umum dan haruslah sejalan dengan konsep res commune yang tidak boleh menjadi objek harga secara ekonomi. Selain itu, Konsep Hak Guna Pakai Air dalam UU SDA harus ditafsirkan sebagai turunan (derivative) dari hak hidup yang dijamin oleh UUD 1945. Oleh karenanya, pemanfaatan air di luar Hak Guna Pakai Air, dalam hal ini Hak Guna Usaha Air, haruslah melalui permohonan izin kepada Pemerintah yang penerbitannya harus berdasarkan pada pola yang disusun dengan melibatkan peran serta masyarakat yang seluasluasnya. Oleh karena itu, Hak Guna Usaha Air tidak boleh dimaksudkan sebagai pemberian hak penguasaan atas sumber air, sungai, danau, atau rawa. Hak Guna Usaha Air merupakan instrumen dalam sistem perizinan yang digunakan Pemerintah untuk membatasi jumlah atau

\footnotetext{
19 Ibid.

${ }^{20}$ Anwar Usman, Wakil Ketua Mahkamah Konstitusi saat pembacaan Pendapat Mahkamah Putusan atas Undang-Undang Sumber Daya Air.
} 
volume air yang dapat diperoleh atau diusahakan oleh yang berhak sehingga dalam konteks ini, izin harus dijadikan instrumen pengendalian, bukan instrumen penguasaan. ${ }^{21}$

Berkaitan dengan PP No. 16 Tahun 2005, ini berarti isi peraturan tersebut merupakan wujud dari privatisasi air. Privatisasi air adalah kegiatan pengelolaan sumber daya air yang didominasi oleh pihak swasta. Privatisasi air terus meningkat karena permintaan yang terus bertambah. Kecenderungan masyarakat untuk mengonsumsi air minum dalam kemasan (AMDK) menjadi penyebab mengapa perusahaan swasta yang menyediakan AMDK terus berkembang. Keterlibatan pihak swasta dalam mengelola air seharusnya bertujuan untuk meningkatkan kualitas penyediaan air bersih bagi rakyat, tetapi kenyataannya perusahaan swasta cenderung untuk mencari keuntungan. Tindakan komersialisasi air inilah yang mengakibatkan akses rakyat untuk mendapatkan air bersih menjadi susah.

Dalam pertimbangannya, MK menyatakan sebagai unsur yang menguasai hajat hidup orang banyak, air sesuai Pasal 33 ayat (2) dan ayat (3) haruslah dikuasai negara. Sehingga, dalam pengusahaan air harus ada pembatasan ketat sebagai upaya menjaga kelestarian dan ketersediaan air bagi kehidupan. Setidaknya, ada lima poin pembatasan yang ditegaskan MK dalam hal pembatasan pengelolaan air.

1. Setiap pengusahaan air tidak boleh mengganggu dan meniadakan hak rakyat. Soalnya, selain dikuasai negara, air ditujukan untuk sebesar-besarnya kemakmuran rakyat;

2. Negara harus memenuhi hak rakyat atas air sebagai salah satu hak asasi manusia, yang berdasarkan Pasal 28 I ayat (4) UUD harus menjadi tanggung jawab pemerintah;

3. Pengelolaan air harus mengingat kelestarian lingkungan;
4. Sebagai cabang produksi yang penting dan menguasai hajat hidup orang banyak air menurut Pasal 33 ayat 2 UUD 1945 harus dalam pengawasan dan pengendalian oleh negara secara mutlak;

5. Hak pengelolaan air mutlak milik negara, maka prioritas utama yang diberikan pengusahaan atas air adalah BUMN atau BUMD.

Pembatalan semua pasal terhadap Undang-Undang Nomor 7 Tahun 2004 Tentang Sumber Daya Air oleh Mahkamah Konstitusi yang dituangkan dalam Amar Putusan Nomor 85/PUU-XI/2013 karena Undang-undang itu dinilai tak sejalan dengan Pasal 33 UUD 1945 mengenai penguasaan atas air oleh negara demi kemakmuran rakyat, sehingga diberlakukannya kembali Undang-Undang Nomor 11 Tahun 1974 tentang Pengairan dan Peraturan Pemerintah Nomor 22 Tahun 1982 Tentang Tata Pengaturan Air.

Pemerintah dalam waktu dekat tidak mempunyai payung hukum untuk melaksanakan pengelolaan SDA di lapangan, karena semua aturan pelaksanaan sebagai turunan dari UU Nomor 7 Tahun 2004 juga dibatalkan. Oleh karena itu aturan payung hukum harus segera diterbitkan.

Turunan aturan pelaksanaan yang mengacu pada UU tersebut jumlahnya cukup banyak, yaitu Peraturan Pemerintah (PP) yang tidak terkait dengan pasal privatisasi/komersialisasi air, misalnya: $P P$ Bendungan, PP Pengelolaan SDA, PP Air Tanah, PP Sungai, PP irigasi, dan PP Rawa. Juga peraturan di bawah PP yang dikeluarkan sebagai peraturan menteri Pekerjaan Umum (Permen PU). Meskipun keputusan MK juga menyatakan bahwa UU No 11 Tahun 1974 tentang pengairan diberlakukan kembali tetapi MK dalam amar keputusannya juga tidak menyatakan bahwa semua aturan pelaksanaan yang mengikuti UU No 11 Tahun 1974 berlaku kembali, dengan demikian semua aturan tesebut juga batal demi hukum karena 
sudah semua aturan pelaksanaan UU No 11 a. Tahun 1974 juga dibatalkan oleh semua tata aturan di bawah UU Nomor 7 Tahun 2004.

Dampak dibatalkannya UndangUndang No 7 Tahun 2004 Tentang Sumber Daya Air bagi Pemerintah (eksekutif), Badan Usaha pengelola Air, dan b. Masyarakat.22

1. Dampak Bagi Pemerintah

a. Berimplikasi kepada perundang-undangan

peraturan sebagai aturan pelaksanaan UU No 7 Tahun c. 2004 tidak berlaku, sehingga sebagai payung hukum diberlakukan kembali UndangUndang Nomor 11 Tahun 1974 Tentang Pengairan;

b. Negara mempunyai hak menguasai Sumber Daya Air, prioritas utama menguasai atas air diberikan kepada Badan Usaha Milik Negara (BUMN) dan Badan Usaha Milik Daerah (BUMD).

2. Dampak bagi Badan Usaha Pengelola Air

a. Dibatalkannya UU No. 7 Tahun 2004 tentang Sumber Daya Air (SDA) berimplikasi turunan peraturan sebagai peraturan pelaksanaannya menjadi batal sehingga hilangnya payung hukum yang menjadi dasar penerbitan ijin pengambilan air bagi Badan Usaha Pengelola Air baik ditingkat pusat maupun daerah;

b. Untuk proses pengusahaan air bagi Badan Usaha Pengelola Air Swasta harus bermitra dengan BUMN atau BUMD diwilayahnya;

c. Akan berdampak pada terhambatnya iklim yang tidak kondusif dan proses investasi yang belum ada kepastian hukumnya untuk mengatur pendirian industri berbasis air di Indonesia.

3. Dampak Bagi Masyarakat :

\footnotetext{
${ }^{22}$ AL. Sentot Sudarwanto, Op.Cit.,
}

Dibatalkannya Undang-Undang Nomor 7 Tahun 2004 tentang Sumber Daya Air akan berdampak positif dalam kehidupan masyarakat secara luas. Artinya semangat hak masyarakat atas air bisa terpenuhi sesuai landasan konstitusional UUD 1945 Pasal 33 Ayat (3);

Kekayaan alam berupa air bisa sepenuhnya dimanfaatkan untuk kemakmuran masyarakat dan kesempatan komersialisasi air oleh perusahaan swasta harus diatur dan diawasi secara ketat;

Akses masyarakat dalam pengelolaan Sumber Daya Air terbuka lebar, artinya harus menempatkan masyarakat pada akses yang lebih besar dalam rangka memperkuat daya tawar masyarakat sipil.

Undang-Undang Republik Indonesia memberikan kesempatan bagi pihak swasta dalam cabang proses produksi termasuk air minum, yang sejatinya untuk kehidupan masyarakat tetapi terbatas dan tidak menghapus kontrol dari negara. Partisipasi swasta dalam menjalankan perusahaan dan dalam langkah-langkah penerapannya tidak membatasi negara untuk mengelola air minum. ${ }^{23}$ Tabel dan gambar dimuat pada halaman terpisah darik teks.

\section{KESIMPULAN}

Negara harus memenuhi hak rakyat atas air mengingat akses masyarakat terhadap air merupakan salah satu Hak Asasi Manusia. Pengusahaan air tidak boleh mengganggu, mengesampingkan apalagi meniadakan hak rakyat atas air. Hal ini sesuai dengan Pasal 33 UUD 1945 yang menyatakan bahwa bumi, air dan kekayaan yang terkandung oleh negara harus dikuasai oleh negara untuk sebesarbesarnya kemakmyran rakyat.

Dampak dibatalkannya UndangUndang No. 7 Tahun 2004 Tentang SDA merupakan angin segar bagi BUMN dan BUMD untuk lebih berkembang dan melaksanakan tugas pokok fungsi Badan Usaha Milik Negara dan Milik Daerah,

\footnotetext{
${ }^{23}$ Agus Surachman dkk, Op.Cit., hlm. 100.
} 
selain berorientasi mencari keuntungan juga tidak boleh ditinggalkan fungsi pelayanan terhadap masyarakat. Selain Undang-Undang No. 7 Tahun 2004 dinyatakan batal hal ini juga berlaku pada peraturan pelaksana yang semuanya juga ikut dibatalkan akibat dibatalkannya Undang-Undang tersebut. Maka MK memberlakukan kembali Undang-Undang No. 11 Tahun 1974 tentang Pengairan.

Dengan diberlakukannya kembali Undang-Undang No. 11 Tahun 1974 tentang Pengairan selagi menunggu Undang-Undang SDA yang baru namun Undang-Undang Pengairan ini belum memiliki peraturan pelaksana yang lengkap sehingga menimbulkan ketidakpastian hukum bagi pelaku usaha dan pemerintah daerah serta masyarakat.

Pemanfaatan air harus mengingat kelestarian fungsi lingkungan hidup sebagai salah satu upaya investasi untuk mencukupi kebutuhan generasi yang akan datang.

Rancangan Undang-Undang Sumber Daya Air yang baru harus memperhatikan ketentuan Pasal 33 UUD 1945 dan tidak hanya untuk kepentingan sekelompok orang dan mengabaikan hak asasi manusia.

\section{SARAN}

1. Pemerintah segera menyiapkan draf Rancangan Undang-Undang (RUU) tentang Sumber Daya Air dan menjamin terlaksananya hak rakyat atas air dan adanya payung hukum sehingga pemerintah tidak bertindak sewenang-wenang dan memberikan kepastian hukum bagi semua pihak;

2. Mengingat proses penyusunan UU dibutuhkan waktu yang relative lama, maka Pemerintah perlu segera menyusun Rancangan Peraturan Pemerintah (RPP) tentang Sumber Daya Air yang mengacu pada UU Nomor 11 Tahun 1974 tentang Pengairan, yang mengatur tentang sistem koordinasi, pembinaan, pengusahaan, perlindungan, dan pembiayaan pengusahaan sumber daya air. RPP dibutuhkan agar kewenangan Pemerintah Provinsi maupun Pemerintah Kabupaten/Kotasegera mempunyai acuan sebagai pijakan yuridis dalam proses menerbitkan izin usaha bagi badan usaha pengelola air maupun bentuk kerjasamaantara Pemerintah dengan unsur swasta.

\section{DAFTAR PUSTAKA}

Anonim, Dampak Privatisasi Air, dapat diakses di http://verlye.blogspot.co.id/2013/02/dampak-privatisasi-air-terhadap.html, diakses pada 8 Desember 2017

Anonim, Ironi Air di Indonesia Menyikapi Potensi Perang Air Belajar Tentang Air dari Swedia" dari Sustaining Partnership Edisi Desember 2011

Anonim, Komersialisasi Air Abaikan Rakyat Miskin RUU Sumber Daya Air Harus Ditinjau Ulang,

dalam http://www.unisosdem.org/article detail.php?aid=2632\&coid=3\&caid=3\&gid= 5, diakses pada 8 Desember 2017

Anonim, MK Bataslkan Undang-Undang Seumber Daya Air, dapat diakses di http://www.hukumonline.com/berita/baca/lt54e4bd8e5dc0a/mk-batalkan-uusumber-daya-air, diakses pada 8 Desember 2017. 
Anonim, Pada 2050 Dua Pertiga Penduduk Dunia Kekurangan Air" dalam http://nationalgeographic.co.id/berita/2012/09/pada-2050-dua-pertigapenduduk-dunia-kekurangan-air, diakses pada 8 Desember 2017.

Anonim, Pembatalan UU Sumber Aaya http://www.mahkamahkonstitusi.go.id/index.php?page=web.Berita\&id=10634\#.W in2-NKWbcc, diakses pada 9 Desember 2017.

Assiddiqie, Jimly. 2004. Konstisusi dan Konstitualisme Indonesia. Jakarta: MKRI \& Pusat Studi HTN FHUI.

Chandranegara, Ibnu Sina. 2012. Ultra Pelitan dan Keadilan menuju Konstitusi, Jakarta: Jurnal Konstitusi. Volume 9 No. 1.

Deklarassi Universal Hak Asasi Manusia

Green Trust Petani 3 September 2010, “Akses Air Untuk Pertanian Berkelanjutan”. Green Trust Petani.

Hernowo, Basah. Kebijakan Nasional Pengelolaan Sumber Daya Air, Direktorat Kehutanan dan Konservasi Sumber Daya Air, Kementrian PPN/BAPPENAS

Manan,Bagir. 2003. Toeri dan Politik Konstitusi. Yogyakarta: FHUII.

Sudarwanto, AL. Sentot. 2015. Dampak Dibatalkannya Undang-Undang Nomor 7 Tahun 2004 Tentang Sumber Daya Air Terhadap Manajemen Air untuk Kesejahteraan Masyarakat, Yustisia. Vol. 4 No. 2 Mei - Agustus.

Surachman dkk, Agus. Effect of Globalization on Establihment of Water Resource Law: A Practice in Indonesia, International Journal of Economic Research ISBN: 0972-9380, Volume 14. No 12 Tahun 2017.

Undang-Undang No. 7 Tahun 2007 tentang Sumber Daya Air.

Usman, Anwar. Wakil Ketua Mahkamah Konstitusi saat pembacaan Pendapat Mahkamah Putusan atas Undang-Undang Sumber Daya Air. 